\title{
Bacterial Exopolysaccharides from Extreme Marine Environments with Special Consideration of the Southern Ocean, Sea Ice, and Deep-Sea Hydrothermal Vents: A Review
}

\author{
C.A. Mancuso Nichols ${ }^{1}$, J. Guezennec ${ }^{2}$ and J.P. Bowman ${ }^{3}$
}

(1) School of Agricultural Science, University of Tasmania, GPO Box 252-54, Hobart, Tasmania, 7000, Australia

(2) Institute Français de Recherche pour l'Exploitation de la Mer, Centre de Brest, DRV/VP, Plouzané, France

(3) Australian Centre of Excellence for Food Safety, University of Tasmania, Hobart, Tasmania, Australia

* C.A.Mancuso@utas.edu.au Phone: +61362262620 Fax: +61 36226 2642:

\begin{abstract}
Exopolysaccharides (EPSs) are high molecular weight carbohydrate polymers that make up a substantial component of the extracellular polymers surrounding most microbial cells in the marine environment. EPSs constitute a large fraction of the reduced carbon reservoir in the ocean and enhance the survival of marine bacteria by influencing the physicochemical environment around the bacterial cell. Microbial EPSs are abundant in the Antarctic marine environment, for example, in sea ice and ocean particles, where they may assist microbial communities to endure extremes of temperature, salinity, and nutrient availability. The microbial biodiversity of Antarctic ecosystems is relatively unexplored. Deep-sea hydrothermal vent environments are characterized by high pressure, extreme temperature, and heavy metals. The commercial value of microbial EPSs from these habitats has been established recently. Extreme environments offer novel microbial biodiversity that produces varied and promising EPSs. The biotechnological potential of these biopolymers from hydrothermal vent environments as well as from Antarctic marine ecosystems remains largely untapped.
\end{abstract}

Keywords: EPSs, polymers, Microbial, hydrothermal, ecosystems 


\section{BACTERIAL EXOPOLYSACCHARIDES FROM EXTREME MARINE} ENVIRONMENTS WITH SPECIAL CONSIDERATION OF THE SOUTHERN OCEAN, SEA ICE AND DEEP-SEA HYDROTHERMAL VENTS - A REVIEW

\section{C.A. Mancuso Nichols ${ }^{1^{\star}}$, J. Guezennec ${ }^{2}$ and J. Bowman ${ }^{3}$}

${ }^{1}$ School of Agricultural Science, University of Tasmania, Hobart, Tasmania, AUSTRALIA,

${ }^{2}$ Institute Français de Recherche pour l'Exploitation de la Mer, Centre de Brest, DRV/VP, Plouzané, France

${ }^{3}$ Australian Centre of Excellence for Food Safety, University of Tasmania, Hobart, Tasmania, AUSTRALIA,

${ }^{\star}$ Corresponding author (School of Agricultural Science, GPO Box 252-54, University of Tasmania, Hobart 7000, AUSTRALIA, Phone +61362262620, FAX +6136226 2642, email C.A.Mancuso@utas.edu.au)

\section{ABSTRACT}

Exopolysaccharides (EPS) are high molecular weight carbohydrate polymers and make up a substantial component of the extracellular polymers that surrounds most microbial cells in the marine environment. EPS comprise a large fraction of the reduced carbon reservoir in the ocean and enhance the survival of marine bacteria by influencing the physico-chemical environment around the cell. Microbial EPS are abundant in the Antarctic marine environment, for example in sea ice and ocean particles, where they may assist microbial communities to endure extremes of temperature, salinity and 
nutrient availability. The microbial biodiversity of Antarctic ecosystems is relatively unexplored. Deep-sea hydrothermal vent environments are characterized by high pressure, temperature and heavy metals. The commercial value of microbial EPS from these habitats has been established recently. Extreme environments offer novel microbial biodiversity that produce varied and promising EPS. The biotechnological potential of these biopolymers from hydrothermal vent environments as well as from Antarctic marine ecosystems remains largely untapped.

\section{INTRODUCTION}

The turnover of organic matter by marine microorganisms is an important component of the global carbon cycle (Azam 1998). Organic material in the oceans exists in a heterogeneous continuum from dissolved to particulate matter and this patchiness can support high bacterial diversity (Azam et al. 1994). Dissolved organic matter in the oceans represents one of the largest reservoirs of reduced carbon on earth (McCarthy et al. 1996). Polysaccharides make up a substantial part of oceanic organic matter, especially in surface waters (Benner et al. 1992, Leppard 1995, McCarthy et al. 1996). Studies of bacteria growing in marine sediments, aggregates and detrital particles, show that nearly all the cells are surrounded by extracellular polymeric material (Decho 1990; Costerton 1999) and many of these cells are enclosed within adherent biofilms (White 1986).

Various macromolecules, such as polysaccharides, proteins, nucleic acids and lipids, form the architectural matrix in the intracellular space of microbial biofilms and unattached aggregates in the marine environment 
(Wingender et al. 1999). The polysaccharide component is the most abundant of these macromolecules since it generally represents $40-95 \%$ of the extracellular polymeric substances (Flemming and Wingender 2001). Abundant microbial polysaccharides present in dissolved organic carbon, particulate material or in biofilms are of major significance in the marine environment. This review provides a brief summary of exopolysaccharide (EPS) biosynthesis, structure-function relationships as well as the role of marine bacterial EPS. We then consolidate what is known so far about the EPS produced by bacteria from two distinct environments, each one experiencing extremes of temperature. There is only a small amount of information in the literature, to the authors' knowledge on the structural elucidation of EPS from Antarctic marine bacteria. As the function is directly related to its chemical structure, structural elucidation will need to be one of the first steps in determining the ecological role of these polysaccharides and establishing whether they are novel or unique. Finally, the commercial potential of EPS produced by bacteria from these two environments is discussed.

\section{REGULATION OF EPS PRODUCTION}

Exopolysaccharide (EPS) is a term first used by Sutherland (1972) to described high molecular weight carbohydrate polymers produced by many marine bacteria. Since that time, EPS also has been used to indicate a more broadly define extracellular polymeric substances (Wingender et al. 1999). Within the context of this review, EPS will be used as it was originally defined, that is to mean exopolysaccharide. 
EPS can be part of the capsular material that closely surrounds the bacterial cell or released into the surrounding environment as dispersed slime with no obvious association to any one particular cell (Sutherland 1982, Decho 1990). In the natural environment, EPS production seems to be essential for survival since most bacteria occur in microbial aggregates whose structural and functional integrity is based on the presence of a matrix of extracellular polymeric substances (Wingender et al. 1999). Analysis of the polysaccharide component of this matrix from specific bacterial members of natural assemblages is difficult due to the low abundance of any one polymer and the complexity of tracing it back to its source (Christensen 1999). The growth of a single strain under controlled conditions is an approach that is used frequently to examine microbial EPS production in order to form theories about the behaviour of these molecules in the natural environment.

\section{Nutrient limitation}

Marine microbes grown in laboratory cultures produce EPS in response to limitation of nutrients such as nitrogen, phosphorus, sulfur and potassium (Sutherland 1982). Exopolymer production may be enhanced in response to physical factors such osmotic stress and temperature (Krembs et al. 2002, Junge et al. 2004). The composition of polysaccharide is generally independent of the nature of the limiting nutrient. When Pseudomonas NCIB 11264 was grown in continuous cultures, its polysaccharide varied little in composition irrespective of $\mathrm{pH}$, temperature, nitrogen, carbon or phosphate content of the growth media (Williams and Wimpenny 1978). The yield of this polymer was higher at suboptimal temperatures, high carbon to nitrogen ratios and during stationary phase. A deep sea hydrothermal vent strain of 
Alteromonas produced EPS at the beginning of stationary phase and during nitrogen limitation, suggesting EPS synthesis for this strain was also induced by restricted growth conditions (Samain et al. 1997). In fact, most deep-sea bacterial isolates examined to date, produce EPS under these conditions (Guezennec, personal observation)

Most bacteria use carbohydrates as a carbon and energy source and amino acids or an ammonium salt as a nitrogen source (Sutherland 1982). The composition of EPS and the chemical and physical properties of these biopolymers can vary greatly (Decho 1990), but it is generally independent of the carbon substrate (Sutherland 1982). Uptake of substrate is one of the first limitations on EPS production and the presence of a carbohydrate substrate such as glucose results in optimal EPS yields (Sutherland 1979). Marine strain Hahella chejuensis produced the highest EPS yield in batch culture when grown on sucrose (Ko et al. 2000). Marine bacteria may also produce EPS during growth in sea water alone (Decho 1990) and during carbon limitation since many species can make use of non-sugar sources for EPS biosynthesis (Sutherland 1979).

\section{Growth phase}

Batch cultures of a deep-sea hydrothermal vent strain of Alteromonas showed stimulated EPS production during nitrogen limited stationary phase (Samain et al. 1997). Most bacteria release the largest quantity of EPS during stationary growth phase in laboratory culture (Decho 1990, Manca et al. 1996). However, a study by Bozal (1994) examined EPS production by a Pseudoalteromonas antarctica $\mathrm{NF}_{3}$ isolated from glacial marine sludge sampled near the South Shetland Islands and found maximum production 
occurred only during exponential phase. The composition of EPS may also vary according to the growth phase of the bacteria (Christensen et al. 1985). Although culture conditions generally do not affect the types of monosaccharides in an EPS, they impact on the functional properties of the polysaccharide such as molecular weight, conformation and monosaccharide ratios (Arias et al. 2003). In natural systems where nutrients levels in close proximity to the bacterial cell may vary considerably, shifts in the physiological state of the cell probably result in variable EPS compositions (Geesey 1982).

\section{BIOSYNTHESIS}

One of the first steps in the biosynthesis of EPS takes place when the substrate enters the cell unaltered or after phosphorylation (Sutherland 1977). EPS is synthesized near the cytoplasmic membrane using activated precursors and carrier molecules. Uridine diphosphate-glucose pyrophosphorylase is a key enzyme producing a precursor for both cell wall polymers and exopolysaccharide biosynthesis in many organisms (Sutherland 1977). Several enzymes involved in nucleotide synthesis are membrane bound. Therefore, it is not clear whether their products occur freely within the cytoplasm or whether they are produced in close proximity to the enzymes that require them for polymer synthesis (Sutherland 1977).

The construction of the repeating units is dependant on the transfer of the appropriate monosaccharides from sugar nucleotides to a carrier lipidisoprenoid alcohol phosphate. The requirement for this carrier lipid in exopolysaccharides biosynthesis is also common to other polymers containing glycan repeating-units located external to the cell membrane 
including peptidoglycan, teichoic acids and lipopolysaccharides (Sutherland 1977, Sutherland 1982). After polymerisation, the polysaccharide chain may be hydrolysed from the isoprenoid carrier lipid by a highly specific enzyme to produce slime (Sutherland 1977). At the same time, the polysaccharide is transported through the inner and outer membranes (Sutherland 1982). In capsule-producing strains, a ligase reaction may remove the polymer chain from the carrier lipid and attach it covalently to an outer membrane protein (Sutherland 1982) or to phospholipid or lipid-A molecules on the cell surface (Roberts 1996). Capsular exopolymer may only be loosely attached (Costerton et al. 1992) to the peptidoglycan layer of the cell wall via S-layers, non-covalently associated proteins or glycoproteins cell and can be shed as amorphous slime (Sidhu and Olsen 1997).

\section{STRUCTURE-FUNCTION RELATIONSHIPS}

Most EPS produced by marine bacteria are heteropolysaccharides consisting of three of four different monosaccharides arranged in groups of ten or less to form repeating units (Decho 1990). The monosaccharides may be pentoses, hexoses, amino sugars or uronic acids. Most polymers are linear overall and of varying lengths with an average molecular weight of $1 \mathrm{x}$ $10^{5}$ to $3 \times 10^{5}$ daltons (Sutherland 1977). Branches of one or more monosaccharides are often attached at regular intervals (Decho 1990). Organic or inorganic (sulphate, phosphate) substituents may also be present. Components most commonly found in marine EPS are listed in Table 1 (adapted from Kenne and Lindberg 1983) 


\section{Influence of functional groups}

The frequency and type of functional groups present in the EPS impact on the tertiary structure and over-all physicochemical characteristic of the polymer in the surrounding aqueous environment (Decho 1990). Exopolymers are highly hydrated molecules (up to 99\% water, Decho 1990, Sutherland 1977). EPS possess hydroxyl and carboxyl groups, which can have a hydrophilic character in aqueous solutions. EPS produced by marine bacteria may contain up to $20-50 \%$ of their EPS as uronic acids $\left(\mathrm{pK}_{\mathrm{a}} 3.2-3.4\right.$, Kennedy and Sutherland 1987). These are carboxylated sugars and they confer a net negative charge and acidic properties to the EPS (Corpe 1970) at the $\mathrm{pH}$ of seawater $(\mathrm{pH} \sim 8)$. Depending on their interaction with other organic and inorganic material in the marine environment, microbial exopolymer may be present in dissolved form or as biofilms and aggregates in a gel-like slime matrix (Flemming et al. 1997). Three types of weak interactions provide cohesive forces, and these include: dispersion forces, electrostatic interactions and hydrogen bonding. Weak interactions are significant when the frequency of the functional groups involved and the size of the polymers are considered (Flemming et al. 1997).

\section{Phylogenetic similarities and differences}

Taxonomic relatedness does not necessarily ensure similarity of EPS structure. Analysis of 32 closely related Halomonas strains, isolated from a hypersaline environment, showed that when grown under the same conditions, EPS yield, chemical composition and physical properties varied from strain to strain (Bouchotroch et al. 2000). The EPS produced by several deep-sea hydrothermal vent bacterial isolates have been well characterized 
(Rougeaux et al. 1996), including two from genus the Pseudoalteromonas.

Despite the strains belonging to two different species, the EPS produced by these deep-sea isolates were very similar with respect to crude chemical and monosaccharide composition. Sulfate content was noted as the only structural difference between the polymers in these two hydrothermal vent strains and this component may have influenced the intrinsic viscosity, which also varied (Table 2).

The results noted above contrast with those presented in other studies (Mancuso Nichols et al. 2004; Mancuso Nichols et al. in press) in which EPS produced by closely related Antarctic strains in the genus Pseudoalteromonas vary substantially in terms of crude chemical composition. Another study found two closely related hydrothermal vent bacteria from different subspecies of Alteromonas macleodii, and isolated from different sites, produced very different EPS under the same growth conditions (CambonBonavita et al. 2002). These EPS show a high metal binding capacity (Loaec et al. 1998) and are thought to aid in attaching bacteria to the hydrothermal chimney as well as lowering the concentrations of toxic heavy metals in the microenvironment (Table 2). EPS produced by the Antarctic marine isolates examined by Mancuso Nichols et al. (2004; in press), included carboxyl groups present in uronic acids, amides present in amino sugars, sulfates and hydroxyl groups, which are abundant in all monosaccharides. The authors suggested metal binding as one potential ecological role for these polymers (Table 2). 


\section{ROLES IN THE MARINE ENVIRONMENT}

Exopolymer production may require an energy expenditure of up to $70 \%$ and this amounts to a significant carbon and energy investment for the bacterial cell (Harder and Dijkhuizen 1983, Wolfaardt et al. 1999). However benefits derived from exopolymer production enhance the growth and survival of microbes and the complex communities in which they are found (Wolfaardt et al. 1999). Extracellular polymers augment the ability of microbes to compete and survive in changing environmental conditions by altering the physical and biogeochemical micro-environment around the cell (Costerton 1974). In the marine environment, bacterial exopolymers and EPS are essential in the production of aggregates (Biddanda 1985, Harris and Mitchell 1973, Alldredge and Silver 1988), adhesion to surfaces and other organisms (Marshall 1985, Fletcher and Floodgate 1973; Paerl 1975, Paerl 1976, Vincent et al. 1994, Holmstrom and Kjelleberg 1999), biofilm formation (Sutherland 2001, Sutherland 1999), sequestering of nutrients (Decho and Herndl 1995), as well as providing protection (Decho and Lopez 1993, Bitton and Friehofer 1978) and ecosystem stability (Uhlinger and White 1983, Dade et al. 1990). The role of microbial exopolymers in the ocean has been reviewed extensively (Decho 1990, Wolfaardt et al. 1999) and is summarized briefly below and in Table 2 . Where information relates to EPS, specific mention is made.

\section{Adhesion to and colonization of surfaces.}

Surfaces exposed to seawater quickly adsorb and concentrate dissolved organic compounds. Attachment to these surfaces by bacteria provides the opportunity for growth in dilute solutions that would otherwise be 
unavailable (Zobell 1943, Paerl 1975). Charged substrates including amino acid, sugars, fatty acids and glycoproteins are often the first concentrated on surfaces (Marshall 1985). Many bacterial cells possess a capsule prior to attachment. Capsular and slime heteropolysaccharides that contain uronic acids ( $\mathrm{pKa} \sim 3$ ) confer a net negative charge to the cell above $\mathrm{pH} 3$ (Sutherland 1980). Since surfaces and cells both tend to be anionic, the presence of positive ions such as $\mathrm{Ca}^{2+}$ is important.

Exopolymers including capsular polysaccharides and proteins are important in bacterial adhesion to surfaces (Wolfaardt et al. 1999). The initial attachment can be reversible and is also related to the electrostatic interactions and cell wall hydrophobicity (van Loosdrecht et al. 1990, van Loosdrecht et al. 1987). Irreversible binding may occur since some bacteria, in close proximity to a surface, secrete large amounts of EPS-slime (Costerton 1984). Additional cross-linking of adjacent EPS chains enable permanent attachment to occur (Marshall 1980). This process is influenced by electrolyte concentration (Fletcher 1988). Bacteria may reversibly attach by secreting an exopolymer allowing them to stick to a surface and use surfaceassociated nutrients (Hermannson and Marshall 1985). This is followed by the secretion of a second polymer, which releases the attached bacterium.

\section{Facilitates biochemical interactions}

Biochemical interactions between the bacteria and surrounding cells and tissues may be made possible by exopolymer material (Logan and Hunt 1987; Decho 1990). Exopolymer slime and capsular material provide a biofilm matrix around the cell. This is a hydrated layer, which can provide a buffering against sudden changes in the adjacent osmotic environment (Dudman 
1977). Such a stable environment may aid in the localisation of secreted exoenzymes, which are essential in the cycling of both organic and inorganic material in the marine environment (Decho 1990). The hydrated exopolymer matrix retains the exoenzymes activity in close proximity to the cell thereby facilitating cellular uptake of small molecules for metabolic conversion to energy and biomass (Decho and Herndl 1995).

Symbiotic relationships may also occur between bacteria and other organisms. Bacteria adhere to the site of nitrogen fixation on cyanobacterial heterocysts (Paerl 1976) via the heterocyst-produced EPS (Lupton and Marshall 1984). These microzones around cells facilitate the transfer of nutrients from one organism to another (Paerl 1976). The heavy metal binding properties of an EPS produced by a hydrothermal vent strain was thought to be advantageous to the tubeworm host. (Vincent et al. 1994). Members of the genera Pseudomonas and Alteromonas produce polysaccharide-containing exopolymers that potentially benefit the survival of other marine organisms by facilitating attachment to surfaces (Szewzyk et al. 1991; Holmstrom and Kjelleberg 1999).

\section{Provides a protective barrier around the cell.}

Exopolymer may act as a physical barrier to grazers. In a study by Caron (1987), microflagellates grazed more readily on freely suspended bacteria than on those on surfaces or enclosed in aggregates. The EPS may have provided protection to cells within the aggregates, since the microflagellates were only able to graze the bacteria on the surface of the aggregates. Slime exopolymer from one bacterial strain may be preferred by 
consumers to the capsular exopolymer of the same strain (Decho and Lopez 1993).

Changes in $\mathrm{pH}$ and salinity over a wide range had little effect on the viscosity and stability of EPS produced by marine bacteria in a study by Boyle and Reade (1983). Such results suggest that these EPS may provide some buffering against shifting environmental conditions in the natural environment. Bacteria isolated from deep-sea hydrothermal vent communities displayed resistance to heavy metals (Jeanthon and Prieur 1990) and the purified EPS produced by these strains in laboratory cultures showed very good metal binding properties (Loaec et al. 1997; Loaec et al. 1998). Capsular polysaccharide may also provide the bacterial cells with a protective barrier against toxic substances in the water column (Bitton and Friehofer 1978).

In biofilm studies involving removal of organic and heavy metal pollutants, exopolymeric substances removed the majority of organic pollutants while heavy metals were taken up by the cellular fraction. These results indicated an important role for cell wall components such as proteins in metal binding in complex biofilm systems (Spaeth et al. 1998). These findings were confirmed in a more recent study that showed heavy metals were bound by cellular sorption as well as extracellularly by polymeric substances such as polysaccharides in bacterial biofilms and microbial flocs (Wuertz et al. 2000).

Cells imbedded in the gel matrix of a biofilm are well protected from biocidal treatments (Brown and Gilbert 1993; McBain and Gilbert 2001). Current strategies to eliminate unwanted biofilms involve the design of antimicrobial agents that can penetrate the gel matrix and target slow or 
dormant cells. Some success has been achieved by incorporating transition metal catalysts into the substratum. These generated biocidal species and killed the biofilm from the inside overcoming the protection provided by the exopolymer matrix (Wood et al. 1998).

\section{Acts as a sponge for sequestering dissolved organic material.}

In natural aquatic environments, the nutrients required to support maximal microbial growth rarely are present in sufficient quantities in the water column. Microbial attachment to fixed surfaces, other cells and aggregates is a likely strategy to increase the rate of substrate uptake (Logan and Hunt 1987). Microbial cells surrounded by a porous matrix of exopolymer sequester and concentrate dissolved organic compounds (Decho and Lopez 1993). The highly hydrated exopolymer matrix act as a sponge to trap and concentrate nutrients in flowing liquids (Decho 1990).

\section{EPS IN THE ANTARCTIC MARINE ENVIRONMENT}

\section{Antarctic sea ice}

\section{Bacteria and exopolymers are abundant}

Bacteria contribute significantly to secondary production in sea ice communities and to the overall carbon cycle in the Antarctic environment. Annual sea-ice is a microhabitat for a complex community of marine bacteria often in close association with microalgae. These assemblages are essential components of carbon and energy transfers in the Southern Ocean (Sullivan and Palmisano 1984). Abundant bacterial populations have been found in thick annual pack ice, with psychrophilic bacteria being particularly common in 
samples of brown ice and pore waters (Delille 1992). Studies of both the Arctic (Krembs and Engel 2001) and Antarctic (Sullivan and Palmisano 1984) sea-ice communities suggest that exopolymer production by both microalgae and bacteria contribute to organic carbon in the sea-ice and ice-water interface. In thick pack ice, bacterial secondary production even exceeds primary production as the light supply to the bottoms layers of ice is reduced (Grossmann and Dieckmann 1994).

Sea ice bacteria maintained in laboratory culture secreted large amounts of mucous (Helmke and Weyland 1995). In a more recent in situ study of bacterial-algal interactions in melting sea ice in the Weddel Sea, it was suggested that bacterial mucous contributed to particulate organic carbon sustaining microbial growth in the sea ice crack pools (Gleitz et al. 1996). Bacterially-produced EPS may provide a means by which bacteria can adhere to the microalgal cells (Sullivan and Palmisano 1984). During ice formation, microalgal cells are scavenged by sea ice crystals floating up to the sea surface (Gleitz and Thomas 1993) and bacteria attached to algal cells may be incorporated into new ice in conjunction with some algal species (Grossmann and Dieckmann 1994).

\section{High salinity, low temperature environments}

Bacteria are found in abundance in the bottom layers of the ice or in brine channels, and are often attached to detrital particles or to living microalgal cells (Sullivan and Palmisano 1984, Archer et al. 1996, Delille and Rosier 1996). Delille and Rosier (1996) also suggested that the high numbers of particle associated bacteria found in sea ice may explain observations of underlying seawater being enriched in bacterial biomass relative to the open 
ocean (Grossmann and Dieckmann 1994). More recently, studies of Arctic sea ice in winter showed that even at temperatures as low as $-20^{\circ} \mathrm{C}$ and salinity of 209 ppt, active bacteria were found in the brine channels and were particle associated (Junge et al. 2004). The same authors showed that high concentrations of exopolymeric substances were found in brine channels and could have been produced by the abundant bacteria or diatom populations present.

A study of Arctic sea ice demonstrated that photosynthesis rates by phytoplankton from under the ice were stimulated to similar levels by sea ice extracts as they were by the chelator, ethylenediamine tetra-acetic acid, and trace metals (Apollonio et al. 2002). From those results, the authors suggested that a natural 'conditioning agent' is produced within the bottom-ice algal layer that enhances phytoplankton growth. Sea ice bacterial communities and high amounts of exopolymer are concentrated in these layers (Krembs and Engel 2001; Krembs et al. 2002). It is yet not clear that in addition to the availability of sufficient light, whether the abundance of trace metals is a limiting nutrient for primary production in sea ice microbial communities.

\section{EPS as a cryoprotectant}

Arctic studies (Krembs and Engel 2001; Krembs et al. 2002) have shown that large quantities of microbially produced exopolymeric substances occur in sea ice and at the ice-water interface. This material was positively correlated to bacterial abundances, although diatoms were thought to dominate the exopolymer production in this system. These authors suggested high concentrations of exopolymer with its high polyhydroxyl content would 
decrease the freezing point of water in the low temperature, high salinity brine channels, especially near the cell, where concentration of exopolymer are highest (Krembs et al. 2002). Exopolymer in the brine channels might have provided buffering against harsh winter conditions and high salinity as well as cryoprotecting the microbes living there against ice crystal formation by depressing the ice nucleation temperature of water (Krembs et al. 2002).

In a recent study (Mancuso Nichols et al. in press), EPS produced by sea ice isolates were shown, by molecular weight analysis to be between 5 and 50 times larger than the average observed for other marine EPS $(1-3 x$ $10^{5}$ Daltons, Decho 1990). The structure and properties of EPS are influenced by the length of the polymer chain, that is the molecular weight (Christensen 1999). As the length of the polymer increases, there is a greater opportunity for complex entanglement of the chains and intramolecular associations, and these contribute to the tertiary structure and physical behavior of the polymer (Sutherland 1994). A fungal strain, Phoma herbarum, isolated from Antarctic soil produced a homosaccharide of glucose with a molecular weight of $7.4 \times 10^{6} \mathrm{Da}$ (Selbmann et al. 2002). The authors of this study suggested that the fungal EPS could have provided a cryoprotective role in the harsh Antarctic environment where the availability of liquid water and temperatures were extremely low. Similarly, the freezing processes in sea ice result in brine channels where temperature is very low and salinity is high due to brine. EPS may be providing a cryoprotectant role in these environments of high salinities and low temperature (Krembs et al. 2002)

In a study by Mancuso Nichols et al. (2004), a strain of Antarctic Pseudoalteromonas isolated from sea ice, produced 30 times as much EPS at 
-2 and $10^{\circ} \mathrm{C}$ compared to $20^{\circ} \mathrm{C}$ in liquid culture. Previous studies have shown that many Pseudoalteromonas strains are psychrotrophic bacteria with a temperature growth range from $4^{\circ} \mathrm{C}$ to $30^{\circ} \mathrm{C}$ (Bozal et al. 1997 ; Bowman 1998), and show optimal growth at $22^{\circ} \mathrm{C}$ to $25^{\circ} \mathrm{C}$ (Bowman 1998). Members of this genus are among the dominant bacteria generally found in this environment as determined by cultivation dependent and independent techniques (Bowman et al. 1997; Staley and Gosink 1999; Brown and Bowman 2001; Brinkmeyer et al. 2003). In the Mancuso Nichols et al. (2004) study, the consumption of glucose per mg of EPS produced was highest at $-2^{\circ} \mathrm{C}$, well below the expected optimal growth temperature for this genus $\left(20^{\circ} \mathrm{C}\right)$. This finding supports the proposed hypothesis that EPS production by psychrotolerant bacteria may play an important role in the sea ice microbial community. Whether this increased EPS production at low temperature is a specific cold adaptation mechanism for this strain requires further investigation. Bacterial EPS production in brine channels and perhaps other cold, high salinity ecosystems may provide a barrier against the environmental extremes experienced by the bacterial cell by modifying water properties near the cell.

Arctic sea ice studies (Krembs and Engel 2001; Krembs et al. 2002) also demonstrated that the neutrally buoyant polymeric material was carried large distances by prevailing under-ice currents and ice drifts. Studies in more temperate waters showed marine bacterial exopolymer production was important in the aggregate formation process (Biddanda 1986; Decho 1990). When released into the water column, a combination of biological, chemical and physical forces caused this colloidal material to form aggregates 
(Alldredge and Jackson 1995; Passow 2000; Kiorboe 2001), which became centers of high microbiological heterotrophic activity (Kiorboe 2001).

\section{EPS in the Southern Ocean}

\section{Marine Snow}

In natural aquatic systems, when exopolymer is associated with particulate material, it exists in particulate form, or it is present in its colloidal form, which is operationally defined as part of the dissolved organic matter (DOM) because it can pass through a filter with a given pore size (less than $0.1 \mu \mathrm{m}$ to $0.46 \mu \mathrm{m}$, Chin et al. 1998). In the oceans, exopolymer exuded by phytoplankton and bacteria coalesce to form transparent exopolymer particles (TEP) that range in size from microns to hundreds of microns (Sullivan and Palmisano 1984; Passow and Alldredge 1994). The aggregation of TEP, phytoplankton, bacteria, faecal pellets, zooplankton and other organic debris form larger particles (>0.5 mm in diameter), which are known as marine snow (Fowler and Knauer 1986, Logan and Hunt 1987; Mueller-Niklas et al. 1994).

\section{Marine snow in the Southern Ocean}

Marine snow has been shown to include highly concentrated and diverse microbial communities (Rath et al. 1998) engaged in photosynthesis, microbial decomposition (Biddanda and Pomeroy 1988, Biddanda 1988) and remineralization of carbon at elevated levels relative to the surrounding sea water (Alldredge and Silver 1988; Simon et al. 1990; Smith et al. 1992). Marine snow particles therefore make a significant contribution to the carbon cycle in the euphotic zone and to the 'biological pump', which transports fixed carbon to deep waters (Alldredge 2000, Kiorboe 2001). The flux of 
aggregates in the Ross Sea, near the Antarctic peninsula, was found to dominate the vertical export of organic matter from the euphotic zone (Asper and Smith 2003). In another study, the abundance of marine snow particles in samples taken near Australian Antarctic bases Davis and Mawson was approximately 100 times lower that observed in the Ross Sea (Marchant et al. 2000). Spatial and temporal variation in particle production and sedimentation has been observed previously in the Antarctic marine environment (Karl et al. 1991). This variation was also consistent with findings from temperate and tropical waters (Alldredge and Silver 1988).

Bacteria in marine aggregates are at an advantage compared to free living cells (Logan and Hunt 1987). Their proximity to other cells and surfaces provides opportunities for interaction and nutrient uptake. Bacterial polysaccharides form the fibrillar frame work, act as glue in the ultrastructure and provide the structural network for microbial associations within marine aggregates (Biddanda 1986; Decho and Herndl 1995; Heissenberger et al. 1996; Lewis 2000; Flemming and Wingender 2001). Microscopic and laboratory studies have shown that bacterially produced EPS have a major role in aggregate formation (Biddanda 1986, Heissenberger and Herndl 1994; Leppard 1995).

\section{EPS as organic ligands}

The ability of bacterial EPS to accumulate metals has been known for some time (Bitton and Friehofer 1978; Brown and Lester 1979; Loaec et al. 1997) and at the $\mathrm{pH}$ of ambient seawater $(\mathrm{pH} \approx 8)$, anionically charged EPS can remove $>99 \%$ of $\mathrm{Zn}$ and $\mathrm{Ag}$ (Harvey and Luoma 1985). Exopolymer complexation with trace metals may impact strongly on the availability of 
these micronutrients to marine organisms and may be important in the downward transport of trace metals and micronutrients in the ocean (Decho 1990). Microbial EPS may also be a major component of the colloidal matter which has been proposed to bind trace metals within an 'onion'-like matrix of metal oxides/hydroxides and organic compounds (Mackey and Zirino 1994). Most $(99 \%)$ dissolved iron in the ocean is bound to organic ligands with a high affinity for iron (Rue and Bruland 1995). Wu et al.(2001) examined the soluble and colloidal iron in the oligotrophic North Atlantic and North Pacific and showed that soluble iron and iron-binding organic ligands were depleted at the surface and enriched at depth. The authors suggested that iron, which was once thought to be dissolved and available to phytoplankton, might be tied up as colloidal material, which eventually aggregates and settles out of the photosynthetic zone. In another study in the subarctic Pacific Ocean, Maldonno and Price (1999) showed that heterotrophic bacteria play a significant role in dissolved iron uptake and that the iron bound to strong organic ligands, the most predominant form of iron in the sea, is available to phytoplankton in these environments.

Trace metal enrichment experiments, conducted in ship-board ultraclean facilities showed that iron may be the most important trace metal controlling phytoplankton development in the Southern Ocean (Scharek et al. 1997) and this has recently been confirmed by field experiments where iron was added to a patch of seawater (Boyd et al. 2000). The iron-stimulated diatom bloom was succeeded by an increase in diatom associated silica particulates in sediment traps at depth after 3 weeks and then by increased particulate organic carbon export to deeper waters. Bacterial remineralization 
and mesozooplankton grazing of this particulate material, which may have included exopolymer material accounted for over half the increased particulates associated with addition of iron to the system. Geider (1999) argued organic ligands produced by microbes keep iron in solution and that microbes are important in the conversion of iron from the particulate to the dissolved phase. As iron is essential for nitrogen fixation, photosynthesis and respiration, the importance in these microbially produced organic ligands to the biogeochemical iron cycle and the broader issue of climate change should not be overlooked.

\section{Implications for primary chemical structure}

Although actual content may vary based upon extraction and purification method used (Neilsen and Andreas 1999), exopolysaccharides

produced by marine bacteria may contain up to $20-50 \%$ of the polysaccharide as uronic acid (Kennedy and Sutherland 1987). The presence of uronic acids contributes a negative charge to the overall polymer (Decho 1990). Sulfate was thought to occur only in polysaccharides produced by Archaea and Cyanobacteria until recently, and its presence in polymers produced by prokaryotes is seen as uncommon (Arias et al. 2003). When sulfate is present as a functional group, it also contributes to the anionic quality of these EPS in seawater (Leppard et al. 1996). The overall negative charge gives the molecule a 'sticky' quality. This anionic charge is important in terms of the affinity of these EPS for binding to cations such as dissolved metals (Brown and Lester 1982).

Korstgens et al (2001) studied biofilms formed by Pseudomonas aeruginosa that were dominated by polysaccharides with carboxyl groups. 
Calcium, copper and iron provided stability to the network by acting as bridging ions. The presence of calcium and magnesium salts resulted in increased viscosity in solutions of polysaccharide from marine bacteria stored at low pH (Boyle and Reade 1983). Divalent cations provide stability to the polysaccharide gel matrix (Decho 1990). Recent work with the purified EPS from $P$ s. aeruginosa showed that there were strong electrostatic interactions between divalent cation manganese and the carboxylate groups occurring along the EPS chain. This study provides insight into the molecular geometry of the stability provided by divalent cations such as calcium, which are present in marine systems (Emmerichs et al. 2004).

Bacteria isolated from Southern Ocean particulate material produced EPS in liquid culture (Mancuso Nichols et al. 2004). Preliminary characterizations show that the structure of the EPS includes sulfate as well as high levels of uronic acids as galacturonic acid, along with acetyl groups. In addition, the EPS was shown by NMR data to include a succinyl group. These features convey an overall polyanionic quality to the EPS in the marine environment, since at the $\mathrm{pH}$ of seawater many of the acidic groups present on these polymers are ionized (Decho 1990). This 'stickiness' is important in terms of the affinity of these EPS for binding of cations such as dissolved metals (Brown and Lester 1982). The EPS produced by Antarctic bacterial isolates examined by Mancuso Nichols et al. (in press) appear to be polyanionic and, therefore, 'sticky' with respect to cations such as trace metals. The availability of iron as a trace metal is of critical importance in the Southern Ocean where it is known to limit primary production (Scharek et al. 1997). Since $99 \%$ of dissolved iron in the ocean is bound to organic ligands 
(Wu et al. 2001), implications for the role of these bacterial polysaccharides in the Antarctic marine environment require further investigation.

Monosaccharide analyses of the ten EPS produced by Antarctic marine bacteria (Mancuso Nichols et al. in press) showed that the sugars present were generally similar to sugars typically found in bacterial EPS (Table 1, Kenne and Lindberg 1983) and more specifically in marine bacterial EPS (Kennedy and Sutherland 1987). Arabinose was present, to varying degrees, in all EPS produced by Antarctic bacteria examined in this study and xylose was present as a minor component in several strains. Arabinose and xylose are not commonly found in bacterial EPS but are components of the lipopolysaccharide layer of some microbes (Kenne and Lindberg 1983). The significance of these finding requires further investigation.

An exopolysaccharide, known as mauran, is produced by the halophilic bacterium, Halomonas maura (Arias et al. 2003). When this strain was grown in media containing salt $(2.5 \%, \mathrm{w} / \mathrm{v})$, it produced a high molecular weight $(4.5$ $x 10^{6}$ Daltons) EPS that contained glucose, mannose and galactose as well as high amounts of glucuronic acid $(8 \%, \mathrm{w} / \mathrm{w})$ and sulfates $(6.5 \%, \mathrm{w} / \mathrm{w})$. This polysaccharide was able to bind a range of heavy metal cations. The authors also noted the stability of muran under different conditions of stress including high salt concentrations and during freezing/thawing. There are similarities between muran and several of the EPS produced by the Antarctic marine isolates in terms of chemical composition.

Further research is necessary to more accurately define the structure of the Antarctic marine bacterial EPS and to relate these findings to the function of these molecules in the natural environment. As yet, it is unclear 
how these polysaccharides may be acting mechanistically as organic ligands, protectants against low temperature or high salinity, or whether the size of these EPS is related to their ecological role. An increased understanding of these structural and functional roles is also a prerequisite to potential biotechnological exploitation of Antarctic bacterial EPS.

\section{EPS FROM THE DEEP-SEA}

\section{Hydrothermal vent communities}

The oceans constitute more that $70 \%$ of the earth's surface. The deep sea $(>1000 \mathrm{~m})$ was once thought to be a biological desert until submarine hydrothermal systems were discovered along mid-ocean ridges at depths greater than 2200 m (Snelgrove and Grassle 1995). Geological formations include hot fumaroles, springs and sediments and deep-sea vents (Stetter 1998). In these environments, hydrostatic pressure averages $25 \times 10^{6}$ Pascals, and temperatures can range from $380^{\circ} \mathrm{C}$ within the fumarole to $2^{\circ} \mathrm{C}$ in the surrounding sea-water (Yayanos 1998). Hot anaerobic waters rich in hydrogen sulfide and heavy metals escape the vents and blend with cold oxygenated seawater. The presence of heavy metals is a characteristic feature of the hydrothermal vent environment (Jeanthon and Prieur 1990). Despite these environmental extremes, a complex food web based on chemosynthesis including dense invertebrate populations supported by a rich microbial community of heterotrophic and autotrophic bacteria were found in the vicinity of the vents (Antoine et al. 1995).

The selective pressures imparted on the inhabitants of this ecosystem result in hydrothermal vent environments being centres of unusual biological 
communities. Vent environments are now considered to be an enormous source of genetic and metabolic microbial biodiversity (Deming and Baross 1998). Innovations in microbiological culturing techniques recently have been employed to gain insight into microbial biochemical processes and microbial by-products used for growth and survival in these hydrothermal vent environments (Deming 1998).

\section{Microbial EPS from hydrothermal vents}

Deep-sea hydrothermal vents offer a new source of a variety of fascinating microorganisms well adapted to these extreme environments. Over the past 17 years, an increasing number of new genera and species of both hyperthermophilic and mesophilic bacteria have been isolated from these vents communities (Guezennec 2002). Bacteria associated with deepsea hydrothermal vent communities have demonstrated their ability to produce unusual extracellular polymers in an aerobic carbohydrate-based medium and so far, three main EPS producing genera have been identified i.e., Pseudoalteromonas, Alteromonas and Vibrio. To date, only a small number of EPS have been fully characterized, since they hold some biotechnological promise (see below). Information related to the chemical composition of these polymers reveals potential commercial usefulness at the same time as providing insight into their role in the deep-sea vent ecosystem.

\section{BIOTECHNOLOGICAL POTENTIAL OF MICROORGANISMS}

Biotechnology is recognised as one of the most promising technologies for the $21^{\text {st }}$ century considering its potential to ameliorate major global problems (disease, malnutrition and environmental pollution), achieve 
industrial sustainability (optimising use of renewable resources, slowing global warming and developing cleaner products and processes) and achieve economic competitiveness (Bull et al. 2000). Since biotechnology is based on the discovery of exploitable biology, the recognition that only a very small fraction of the earth's microbial biodiversity has been identified implies a great potential for innovation. Knowledge of the interaction of microbes in their environment is critical in accessing both the microbe itself and processes it employs to survive, both of which hold biotechnological promise (Bull et al. 2000).

\section{Biotechnological potential of EPS}

The species-specific structural heterogeneity and the many roles EPS play in the natural environment are reflected in the numerous existing and potential applications for these bio-polymers (Weiner 1997). Xanthan gum, the most well known microbial polysaccharide, is produced by the plantpathogen Xanthomonas campestris pv. campestris. Because of its physical properties it is commonly used as a thickener in both food and non-food industries (Becker et al. 1998). Bacterial cellulose, produced by Acetobacter xylinum and other, mainly Gram-negative bacterial species, has a high water binding capacity. This EPS is used to make a type of wound dressing for patients with burns, chronic ulcers or extensive tissue loss (Sutherland 1998). Several Agrobacterium and Rhizobium species produce curdlan and this improves the texture of tofu, bean jelly and fish pastes in Japan (Sutherland 1998). The study of EPS produced by bacteria from the marine environment provides additional opportunities for novel uses of these biopolymer 


\section{EPS from deep-sea hydrothermal vents}

In recent years, there has been a growing interest in the isolation and identification of new microbial polysaccharides that may have novel applications such as viscosifiers, gelling agents, emulsifiers, stabilizers and texture enhancers. In the course of the discovery of novel polysaccharides of biotechnological interest, it is now widely accepted that extremophilic microorganisms will provide a valuable resource not only for exploitation in biotechnological processes but also as models for investigating how biomolecules are stabilized when subjected to extreme conditions. Deep-sea hydrothermal vents offer a new source of novel bacteria. Several have been found to produce exopolymers with exploitable properties.

EPS-producing thermophilic and mesophilic strains have been sourced from vent environments and the EPS produced by these strains in laboratory culture have been examined for a range of applications. Several bacterial exopolymers were found to be novel with significant biotechnological potential (Guezennec et al. 1994, Raguénès et al. 1997b). To date, investigations generally have been performed on mesophilic heterotrophic bacteria rather than on thermophilic and hyperthermophilic microorganisms. This is despite the biotechnological appeal of microorganisms adapted to life at high temperature that may produce thermostable enzymes (Guezennec 2002).

The structure of the EPS produced by Pseudoalteromonas strain 721 has been investigated. The repeating unit of this polymer shows some irregularities but can be defined as an octasaccharide with two side-chains (Figure 1, Rougeaux et al. 1999). This exopolymer exhibits a gelation following thermal treatment. The viscoelastic behaviour of the HYD721/ $\mathrm{NaCl}$ 
system under varying temperatures suggests that two effects contribute to the creation of the gel network. Intermolecular associations observed with increasing temperature are probably the result of hydrophobic interactions between methyl groups of the rhamnose residues (Guezennec 2002).

Alteromonas strain 1545, isolated near a hydrothermal vent from the epidermis of the polychaete Alvinella pompejana, produces an anionic EPS under laboratory conditions (Talmont et al. 1991). A polysaccharide secreted by a bacterium (Alteromonas strain 1644) isolated from Alvinellidae samples, collected near a hydrothermal vent of the East Pacific Rise showed an original chemical structure and unique rheological behaviour (Figure 2). This polymer shows strong selectivity between monovalent and divalent ions and exhibits a great affinity for the divalent ions, higher than predicted by electrostatic theories (Bozzi et al. 1996a; Bozzi et al. 1996b) with the exception for $\mathrm{Mg}^{2+}$. A. macleodii subsp. fijiensis is an aerobic, mesophilic, heterotrophic bacterium isolated from a diluted hydrothermal vent at a depth of $2600 \mathrm{~m}$ in a rift system of the North Fiji basin $\left(16^{\circ} 59^{\prime} \mathrm{S}, 173^{\circ} 55^{\prime} \mathrm{W}\right)$. This strain produces an EPS with a high metal-binding maximum capacity (up to $316 \mathrm{mg} \mathrm{Pb}$ (II) / g polymer (Loaec et al. 1997; Loaec et al. 1998). Proposed uses for this polymer include water treatment and removal of heavy metal pollutants (Table 2). This EPS also holds promise as a food-thickening agent since it has many chemical similarities to xanthan (Figure 3, Rougeaux et al. 1996). This hydrophobic bacterial exopolysaccharide was also shown to encourage adhesion of osteoblastic cells during in vivo experiments conducted on rat calvaria. Results suggested that hydrophobic EPS matrix added to bone surfaces might encourage healing (Zanchetta and Guezennec 2001). Other studies of 
EPS produced by bacteria from these vent environments either in their native state or following chemical modifications also suggested clinical applications in the area of cardio-vascular diseases (Colliec-Jouault et al. 2001; Matou et al. submitted) and bone healing.

A facultatively anaerobic, heterotrophic and mesophilic bacterium was also isolated from a Pompeii worm (polychaete Alvinella pompejana) tube collected from a deep-sea hydrothermal field of the East Pacific Rise and named Vibrio diabolicus. This was the first member of the genus Vibrio to be isolated from a deep-sea ecosystem. Novel EPS produced by this strain is characterized by equal amounts of uronic acid and hexosamine ( $N$-acetyl glucosamine and $\mathrm{N}$-acetyl galactosamine (Figure 4, Raguénès et al. 1997a).The role of this novel bacterial polysaccharide in bone regeneration has been recently successfully investigated (Zanchetta et al. 2003a; Zanchetta et al. 2003b).

There is not doubt that extreme environments such as deep-sea hydrothermal vents are a rich source of microorganisms of biotechnological importance. A number of interesting and unique polysaccharides have been isolated from these microorganisms and these are expected to find industrial applications in the very near future. Further screenings are underway as well as research into understanding the structure-function relationships of these unusual polymers (Guezennec 2002).

\section{Cool prospects: EPS from Antarctica}

The Antarctic marine environment is perennially cold, in some cases it is permanently ice covered. Extremes of temperature, salinity, and water activity govern microbial life in enriched microenvironments for example, 
hypersaline sea ice brine channels, the pelagic water column and particles. Spatial heterogeneity combined with extreme seasonal fluctuations such as those experienced during annual sea ice formation events results in a high diversity of microbial habitats and therefore, microbial communities (Karl 1993). Very few bacterial species isolated from the Antarctic marine environment have been described to date (Nichols et al. 2001). An opportunity clearly exists for the search and discovery of novel microbial products with biotechnological potential.

Ecological studies examining the role of EPS in marine habitats now provide evidence that these substances are abundant in the Antarctic marine environment (Helmke and Weyland 1995; Krembs and Engel 2001; Krembs et al. 2002, Mancuso Nichols et al. 2004; Mancuso Nichols et al. in press). However, few studies focusing on the biotechnological potential of EPS produced by bacteria from the Antarctic marine environment are available from the literature to date. Pseudoalteromonas antarctica $\mathrm{NF}_{3}$ produces a exopolymeric compound of glycoprotein character that displays the ability to coat liposomes and provides protection against surfactants (Cocera et al. 2000; Cocera et al. 2001). A study by Mancuso Nichols et al. (in press) has shown that, even among closely related strains, EPS produced by Antarctic bacteria commonly found in the marine environment were diverse. The full subunit structure of EPS produced by Antarctic marine bacteria remains to be elucidated. This information will facilitate assessment of possible commercial applications. These initial studies reveal largely untapped reservoir of biotechnological potential is waiting to be accessed. Whether these EPS will 
become useful as cryoprotectants, chelators of heavy metals or in some other form remains to be established.

\section{CONCLUSIONS}

Bacterial exopolymers and their EPS components are abundant and ubiquitous in the marine environment where they serve essential functions that enhance microbial survival. In the Antarctic marine environment, exopolymers may provide cryoprotection in high salinity, low temperature brine channels. In the Southern Ocean iron limits primary productivity and the resulting draw-down of carbon dioxide, an important green house gas, from the atmosphere. Microbial EPS in suspended aggregates of marine snow, may influence the availability of dissolved iron for primary production in Antarctic waters. In hydrothermal vent environments of the deep-sea, where bacteria have adapted to physical stresses such as extremes of temperature and pressure, exopolymers have been found that produce biochemically interesting EPS. The two environments highlighted in this review provide examples of reservoirs of microbial biodiversity that are relatively untapped.

Several EPS produced by microbes from these extreme environments are showing biotechnological promise. By examining the chemical characteristics of these carbohydrate polymers, it is possible to begin to understand the ecological role of these natural products as well as to gain insight into their commercial potential.

\section{ACKNOWEDGEMENTS}

The authors would like to acknowledge Drs June Olley and Peter Nichols for their careful reading and helpful suggestions during the 
preparation of this manuscript. The efforts of three anonymous referees are acknowledged as their comments significantly improved this review. CMN was supported by a Tasmanian Post-graduate Research Scholarship and by funding provided by the Australian Antarctic Division. CMN also received a travel award from the Australian Academy of Science and the French Embassy in Canberra, Australia. 


\section{REFERENCES}

Alldredge, A. (2000). Interstitial dissolved organic carbon (DOC) concentrations within sinking marine aggregates and their potential contribution to carbon flux. Limnol Oceanogr 45:1245-1253.

Alldredge, A. and Jackson, G. A. (1995). Aggregation in marine systems. Deep-Sea Res Pt I/ 42:1-7.

Alldredge, A. and Silver, M. W. (1988). Characteristics, dynamics, and significance of marine snow. Prog Oceanogr 20:41-82.

Antoine, E., Guezennec, J., Meunier, J. R., Lesongeur, F. and Barbier, G. (1995). Isolation and characterization of extremely thermophilic Archaebacteria related to the genus Thermococcus from deep-sea hydrothermal Guaymas basin. Curr Microbiol 31:186-192.

Apollonio, S., Pennington, M. and Cota, G. F. (2002). Stimulation of phytoplankton photosynthesis by bottom-ice extracts in the Arctic. Polar Biol 25:350-354.

Archer, S. D., Leakey, R. J. G., Burkill, P. H., Sleigh, M. A. and Appleby, C. J. (1996). Microbial ecology of sea ice at a coastal Antarctic site: community composition, biomass and temporal change. Mar Ecol-Prog Ser 135:179-195.

Arias, S., del Moral, A., Ferrer, M. R., Tallon, R., Quesada, E. and Béjar, V. (2003). Mauran, an exopolysaccharide produced by the halophilic bacterium Halomonas maura, with a novel composition and interesting properties for biotechnology. Extremophiles 7:319-326.

Asper, V. L. and Smith, J., Walker O. (2003). Abundance, distribution and sinking rates of aggregates in the Ross Sea, Antarctica. Deep-Sea Res Pt I 50:131-150.

Azam, F. (1998). Microbial control of oceanic carbon flux. Science 280:694696.

Azam, F., Smith, D. C., Steward, G. F. and Hagstrom, A. (1994). Bacteria organic-matter coupling and its significance for oceanic carbon cycling. Microb Ecol 28:167-179.

Becker, A., Katzen, F., Puhler, A. and lelpi, L. (1998). Xanthan gun biosynthesis and application: a biochemical/genetic perspective. Appl Microbiol Biotechnol 50:145-152.

Benner, R., Pakulski, J. D., McCartney, M., Hedges, J. I. and Hatcher, P. G. (1992). Bulk chemical characteristics of dissolved organic matter in the ocean. Science 255:1561-1564. 
Biddanda, B. A. (1985). Microbial synthesis of macroparticulate matter. Mar Ecol-Prog Ser 20:241-251.

Biddanda, B. A. (1986). Structure and function of microbial aggregates. Oceanol Acta 9:209-211.

Biddanda, B. A. (1988). Microbial aggregation and degradation of phytoplankton-derived detritus in seawater. II. Microbial metabolism. Mar Ecol-Prog Ser 42:89-95.

Biddanda, B. A. and Pomeroy, L. R. (1988). Microbial aggregation and degradation of phytoplankton-derived detritus in seawater. I. Microbial succession. Mar Ecol-Prog Ser 42:79-88.

Bitton, G. and Friehofer, V. (1978). Influence of extracellular polysaccharide on the toxicity of copper and cadmium toward Klebsiella aerogenes. Microb Ecol 4:119-125.

Bouchotroch, S., Quesada, E., Izquierdo, I., Rodriguez, M. and Bejar, V. (2000). Bacterial exopolysaccharides produced by newly discovered bacteria belonging to the genus Halomonas, isolated from hypersaline environments in Morocco. J Ind Microbiol Biot 24:374-378.

Bowman, J. P. (1998). Pseudoalteromonas prydzensis sp. nov., a psychrotrophic, halotolerant bacterium from Antarctic sea ice. Int J Syst Bacteriol 48:1037-1041.

Bowman, J. P., McCammon, S. A., Brown, M. V., Nichols, D. S. and McMeekin, T. A. (1997). Diversity and association of psychrophilic bacteria in Antarctic sea ice. Appl Environ Microbiol 63:3068-3078.

Boyd, P. W., Watson, A. J., Law, C. S., Abraham, E. R., Trull, T., Murdoch, R., Bakker, D. C. E., Bowie, A. R., Buesseler, K. O., Chang, H., Charette, M., Croot, P., Downing, K., Frew, R., Gall, M., Hadfield, M., Hall, J., Harvey, M., Jameson, G., LaRoche, J., Liddicoat, M., Ling, R., Maldonado, M. T., McKay, R. M., Nodder, S., Pickmere, S., Pridmore, R., Rintoul, S., Safi, K., Sutton, P., Strzepek, R., Tanneberger, K., Turner, S., Waite, A. and Zeldis, J. (2000). A mesoscale phytoplankton bloom in the polar Southern Ocean stimulated by iron fertilization. Nature 407:695-702.

Boyle, C. D. and Reade, A. E. (1983). Characterization of two extracellular polysaccharides from marine bacteria. Appl Environ Microbiol 46:392-399.

Bozal, N., Manresa, A., Castellvi, J. and Guinea, J. (1994). A new bacterial strain of Antarctica, Alteromonas sp. that produces a heteropolymer slime. Polar Biol 14:561-567.

Bozal, N., Tudela, E., Rossello-Mora, R., Lalucat, J. and Guinea, J. (1997). Pseudoalteromonas antarctica sp. nov., isolated from an Antarctic coastal environment. Int J Syst Bacteriol 47:345-351. 
Bozzi, L., Milas, M. and Rinaudo, M. (1996a). Characterization and solution properties of a new exopolysaccharide excreted by the bacterium Alteromonas sp strain 1644. Int J Biol Macromol 18:9-17.

Bozzi, L., Milas, M. and Rinaudo, M. (1996b). Solution and gel rheology of a new exopolysaccharide excreted by the bacterium Alteromonas sp strain 1644. Int J Biol Macromol 18:83-91.

Brinkmeyer, R., Knittel, K., Jurgens, J., Weyland, H., Amann, R. and Helmke, E. (2003). Diversity and structure of bacterial communities in Arctic versus Antarctic pack ice. Appl Environ Microbiol 69:6610-6619.

Brown, M. J. and Lester, J. N. (1979). Metal removal in activated sludge: the role of bacterial extracellular polymers. Water Res 13:817-837.

Brown, M. J. and Lester, J. N. (1982). Role of bacterial extracellular polymers in metal uptake in pure bacterial culture and activated sludge - I. Water Res 16:1539-1548.

Brown, M. R. W. and Gilbert, P. (1993) Sensitivity of biofilms to antimicrobial agents. In Microbial Envelopes: Interactions and Biofilm, Vol. 74 (Eds, Quesnel, L. B., Gilbert, P. and Handley, P. S.) Journal of Applied Bacteriology Supplement, pp. 87S-97S.

Brown, M. V. and Bowman, J. P. (2001). A molecular phylogenetic survey of sea-ice microbial communities (SIMCO). FEMS Microbiol Ecol 35:267-275.

Bull, A. T., Ward, A. C. and Goodfellow, M. (2000). Search and discovery strategies for biotechnology:the paradigm shift. Microbiol Mol Biol Rev 64:573-606.

Cambon-Bonavita, M.-A., Raguénès, G., Jean, J., Vincent, P. and Guezennec, J. (2002). A novel polymer produced by a bacterium isolated from a deep-sea hydrothermal vent polychaete annelid. J Appl Microbiol 93:310-315.

Caron, D. A. (1987). Grazing of attached bacteria by heterotrophic microflagellates. Microb Ecol 13:203-218.

Chin, W.-C., Orellana, M. V. and Verdugo, P. (1998). Spontaneous assembly of marine dissolved organic matter into polymer gels. Nature 391:568-571.

Christensen, B. E. (1999) Physical and chemical properties of extracellular polysaccharides associated with biofilms and related substances. In Microbial Extracellular Substances - characterization, structure and function, (Eds, Wingender, J., Neu, T., R. and Flemming, H.-C.) Springer, New York, pp. 144-154.

Christensen, B. E., Kjosbakken, J. and Smidsrod, O. (1985). Partial chemical and physical characterization of two extracellular polysaccharides produced 
by marine, periphytic Pseudomonas sp. strain NCMB 2021. Appl Environ Microbiol 50:837-845.

Cocera, M., Lopez, O., Parra, J. L., Mercade, M. E., Guinea, J. and de la Maza, A. (2000). Protective effect caused by the exopolymer excreted by Pseudoalteromonas antarctica $\mathrm{NF}_{3}$ on liposomes against the action of octyl glucoside. Int J Pharm 207:39-47.

Cocera, M., Lopez, O., Sabes, M., Parra, J. L., Guinea, J. and de la Maza, A. (2001). Assembly properties and application of a new exopolymeric compound excreted by Pseudoalteromonas antarctica $\mathrm{NF}_{3}$. J Biomater SciPolym Ed 12:409-427.

Colliec-Jouault, S., Chevolet, L., Helley, D., Ratiskol, J., Bros, A., Sinquin, C., Roger, O. and Fischer, A. M. (2001). Characterization, chemical modifications and in vitro anticoagulant properties of an exopolysaccharide produced by Alteromonas infernus. Biochimica et Biophysica Acta 1528:141-151.

Corpe, W. A. (1970). An acid polysaccharide produced by primary film forming bacteria. Dev Ind Microbiol 16:249-255.

Costerton, J. W. (1974). Structure and function of the cell envelope of gramnegative bacteria. Bacteriol Rev 38:87-110.

Costerton, J. W. (1984) Mechanisms of microbial adhesion to surfaces. Direct ultrastructural examinations of adherent bacterial populations in natural pathogenic ecosystems. In Current Perspectives in Microbial Ecology, Prog 3rd Int Symp Microbial Ecol(Eds, Klug, M. J. and Reddy, C. A.), pp. 115-123.

Costerton, J. W. (1999). The role of bacterial exopolysaccharides in nature and disease (Reprinted from Developments in Industrial Microbiology, vol 26, pp 249-261, 1985). J Ind Microbiol Biot 22:551-563.

Costerton, J. W., Lappin-Scott, H. M. and Cheng, K.-J. (1992) Glycocalyx, bacterial. In Encyclopedia of Microbiology, Vol. 2 (Ed, Lederberg, J.) Academic Press, San Diego, pp. 311-317.

Dade, W. B., Davis, J. D., Nichols, P. D., Nowell, A. R. M., Thistle, D., Trexler, M. R. and White, D. C. (1990). Effects of exopolymer adhesion on the entrainment of sand. Geomicrobiol J 8:1-16.

Decho, A. W. (1990) Microbial exopolymer secretions in ocean environments: their role(s) in food webs and marine processes. In Oceanogr Mar Biol Annu Rev, (Ed, Barnes, M.) Aberdeen Univ Press, Aberdeen, pp. 73-153.

Decho, A. W. and Herndl, G. J. (1995). Microbial Activities and the transformation of organic matter within mucilaginous material. Sci Total Environ 165:33-42. 
Decho, A. W. and Lopez, G. R. (1993). Exopolymer microenvironments of microbial flora - multiple and interactive effects on trophic relationships.

Limnol Oceanogr 38:1633-1645.

Delille, D. (1992). Marine bacterioplankton at the Weddell sea ice edge, distribution of psychrophilic and psychrotrophic populations. Polar Biol 12:205-210.

Delille, D. and Rosier, C. (1996). Seasonal changes of Antarctic marine bacterioplankton and sea ice bacterial assemblages. Polar Biology 16:27-34.

Deming, J. W. (1998). Deep ocean environmental biotechnology. Curr Opin Biotechnol 9:283-287.

Deming, J. W. and Baross, J. A. (1998) Survival, dormancy and nonculturable cells in extreme deep-sea environments. In Non-culturable organisms in the environment, (Eds, Colwell, R. R. and Grimes, D. J.) Chapman and Hall, New York.

Dudman, W. F. (1977) The role of surface polysaccharides in natural environments. In Surface Carbohydrates of the Procaryotic Cell, (Ed, Sutherland, I. W.) Academic Press, New York, pp. 357-414.

Emmerichs, N., Wingender, J., Flemming, H.-C. and Mayer, C. (2004). Interaction between alginates and manganese cations: identification of preferred binding sites. Int J Biol Macromol 34:73-79.

Flemming, H.-C. and Wingender, J. (2001). Relevance of microbial extracellular polymeric substances (EPSs) - Part I: Structural and ecological aspects. Water Sci Technol 43:1-8.

Flemming, H.-C., Wingender, J., Moritz, R., Borchard, W. and Mayer, C. (1997) Physico-chemical properties of biofilm - a short review. In Biofilms in the Aquatic Environment, (Eds, Keevil, C. W., Godfree, A., Holt, D. and Dow, C.) The Royal Society of Chemistry, Cambridge, UK, pp. 1-12.

Fletcher, M. (1988). Effects of electrolytes on the attachment of aquatic bacteria to solid surfaces. Estuaries 11:226-230.

Fletcher, M. and Floodgate, G. D. (1973). An electron microscopic demonstration of an acidic polysaccharide involved in adhesion of a marine bacterium to solid surfaces. J Gen Microbiol 74:325-334.

Fowler, S. W. and Knauer, G. A. (1986). Role of large particles in the transport of elements and organic compounds through the oceanic water column. Prog Oceanogr 16:147-194.

Geesey, G. G. (1982). Microbial exopolymers:ecological and economic considerations. Amer Soc Microbiol News 48:9-14.

Geider, R. J. (1999). Complex lessons of iron uptake. Nature 400:815-816. 
Gleitz, M., Grossmann, S., Scharek, R. and Smetacek, V. (1996). Ecology of diatom and bacterial assemblages in water associated with melting summer sea ice in the Weddell sea, Antarctica. Antarct Sci 8:135-146.

Gleitz, M. and Thomas, D. N. (1993). Variation in phytoplankton standing stock, chemical composition and physiology during sea-ice formation in the southeastern Weddell Sea. J Exp Mar Biol Ecol 173:211-230.

Grossmann, S. and Dieckmann, G. S. (1994). Bacterial standing stock, activity and carbon production during formation and growth of sea ice in the Weddell Sea. Appl Environ Microbiol 60:2746-2753.

Guezennec, J. (2002). Deep-sea hydrothermal vents: A new source of innovative bacterial exopolysaccharides of biotechnological interest? J Ind Microbiol Biot 29:204-208.

Guezennec, J., Pignet, P., Raguénès, G., Deslandes, E., Lijour, Y. and Gentric, E. (1994). Preliminary chemical characterization of unusual eubacterial exopolysaccharides of deep-sea origin. Carbohydr Polym 24:287294.

Harder, W. and Dijkhuizen, L. (1983). Physiological Responses to Nutrient Limitation. Ann Rev Microbiol 37:1-23.

Harris, R. H. and Mitchell, R. (1973). The role of polymers in microbial aggregation. Ann Rev Microbiol 27:27-50.

Harvey, R. W. and Luoma, S. N. (1985). Effect of adherent bacteria and bacterial extracellular polymers upon assimilation by Macoma baltica of sediment-bound Cd, Zn and Ag. Mar Ecol-Prog Ser 22:281-289.

Heissenberger, A. and Herndl, G. J. (1994). Formation of high molecular weight material by free-living marine bacteria. Mar Ecol-Prog Ser 111:129135.

Heissenberger, A., Leppard, G. G. and Herndl, G. J. (1996). Ultrastructure of marine snow II. Microbiological considerations. Mar Ecol-Prog Ser 135:211308.

Helmke, E. and Weyland, H. (1995). Bacteria in the sea ice and underlying water on the eastern Weddell Sea in midwinter. Mar Ecol-Prog Ser 117:269287.

Hermannson, M. and Marshall, K. C. (1985). Utilization of surface localized substrate by non-adhesive marine bacteria. Microb Ecol 11:91-105.

Holmstrom, C. and Kjelleberg, S. (1999). Marine Pseudoalteromonas species are associated with higher organisms and produce biologically active extracellular agents. FEMS Microbiol Ecol 30:285-293. 
Jeanthon, C. and Prieur, D. (1990). Susceptibility to heavy metals and characterization of heterotrophic bacteria isolated from two hydrothermal vent polychaete annelids, Alvinella pompejana and Alvinella caudata. Appl Environ Microbiol 56:3308-3314.

Junge, K., Eicken, H. and Deming, J. W. (2004). Bacterial Activity at -2 to $20^{\circ} \mathrm{C}$ in Arctic Wintertime Sea Ice. Appl Environ Microbiol 70:550-557.

Karl, D. M. (1993) Microbial processes in the Southern Ocean. In Antarctic Microbiology, (Ed, Friedmann, E. I.) John Wiley and Sons, New York, pp. 164.

Karl, D. M., Tilbrook, B. D. and Tien, G. (1991). Seasonal coupling of organic matter production and particle flux in the western Bransfield Straight, Antarctica. Deep-Sea Res 38:1097-1126.

Kenne, L. and Lindberg, B. (1983) Bacterial Polysaccharides. In The Polysaccharides, Vol. 2 (Ed, Aspinall, G. O.) Academic Press, New York, pp. 287-363.

Kennedy, A. F. D. and Sutherland, I. W. (1987). Analysis of bacterial exopolysaccharides. Biotechnol Appl Biochem 9:12-19.

Kiorboe, T. (2001). Formation and fate of marine snow: small-scale processes with large scale implications. Sci Mar 65:57-71.

Ko, S.-H., Lee, H. S., Park, S. H. and Lee, H. K. (2000). Optimal conditions for the production of exopolysaccharide by marine microorganism Hahella chenjuensis. Biotechnol Bioprocess Eng 5:181-185.

Korstgens, V., Flemming, H.-C., Wingender, J. and Borchard, W. (2001). Influence of calcium ions on the mechanical properties of a model biofilm of mucoid Pseudomonas aeruginosa. Water Sci Technol 43:49-57.

Krembs, C., Eicken, H., Junge, K. and Deming, J. W. (2002). High concentrations of exopolymeric substances in Arctic winter sea ice: implications for the polar ocean carbon cycle and cryoprotection of diatoms. Deep-Sea Res Pt / 49:2163-2181.

Krembs, C. and Engel, A. (2001). Abundance and variability of microorganisms and transparent exopolymer particles across ice-water interface of melting first-year sea ice in the Laptev Sea (Arctic). Mar Biol 138:173-185.

Leppard, G. G. (1995). The characterization of algal and microbial mucilages and their aggregates in aquatic ecosystems. Sci Total Environ 165:103-131.

Leppard, G. G., Heissenberger, A. and Herndl, G. J. (1996). Ultrastructure of marine snow. I. Transmission electron microscopy methodology. Mar EcolProg Ser 135:289-298. 
Lewis, K. (2000). Programmed death in bacteria. Microbiol Mol Biol Rev 64:503-514.

Loaec, M., Olier, R. and Guezennec, J. (1997). Uptake of lead, cadmium and zinc by a novel bacterial exopolysaccharide. Water Res 31:1171-1179.

Loaec, M., Olier, R. and Guezennec, J. (1998). Chelating properties of bacterial exopolysaccharides from deep-sea hydrothermal vents. Carbohydr Polym 35:65-70.

Logan, B. E. and Hunt, J. R. (1987). Advantages to microbes of growth in permeable aggregates in marine systems. Limnol Oceanogr 32:1034-1048.

Lupton, F. S. and Marshall, K. C. (1984) Mechanisms of specific bacterial adhesion to cyanobacterial heterocysts. In Current Perspectives in Microbial Ecology, (Eds, Klug, M. J. and Reddy, C. A.) American Society for Microbiology, Washnington, DC.

Mackey, D. J. and Zirino, A. (1994). Comments on Trace-Metal Speciation in Seawater or Do Onions Grow in the Sea. Anal Chim Acta 284:635-647.

Maldonado, M. and Price, N. M. (1999). Utilization of iron bound to strong organic ligands by plankton communities in the subarctic Pacific Ocean. Deep-Sea Res Pt I/ 46:2447-2473.

Manca, M. C., Lama, L., Improta, R., Esposito, A., Gambacorta, A. and Nicolaus, B. (1996). Chemical composition of two exopolysaccharides from Bacillus thermoantarcticus. Appl Environ Microbiol 62:3265-3269.

Mancuso Nichols, C., Garon Lardiere, S., Bowman, J. P., Nichols, P. D., Gibson, J. A. E. and Guezennec, J. (in press). Chemical characterization of exopolysaccharides from Antarctic marine bacteria. Microb Ecol.

Mancuso Nichols, C., Garon, S., Bowman, J. P., Raguénès, G. and Guezennec, J. (2004). Production of exopolysaccharides by Antarctic marine bacterial isolates. J Appl Microbiol 96:1057-1066.

Marchant, H., Davidson, A., Wright, S. and Glazebrook, J. (2000). The distribution and abundance of viruses in the Southern Ocean during spring. Antarct Sci 12:414-417.

Marshall, K. C. (1980) Bacterial adhesion in natural environments. In Microbial adhesion to surfaces, (Ed, Berkeley, R. C. W.) Ellis Howood Limited, Chichester, pp. 187-196.

Marshall, K. C. (1985) Mechanisms of bacterial adhesion at solid-water interfaces. In Bacterial Adhesion, (Eds, Savage, D. C. and Fletcher, M.) Plenum Press, New York, pp. 133-161.

Matou, S., Colliec-Jouault, S., Ratiskol, J., Sinquin, C., Guezennec, J., Fischer, A. M. and Helley, D. (submitted). Effect of oversulfated 
exopolysaccharide on angiogenisis induced by FGF-2 or VEGF in vitro. Biochemical Pharmceutical.

McBain, A. and Gilbert, P. (2001) Biofilms: adverse economic impacts and their avoidance, Royal Society for Chemistry.

McCarthy, M., Hedges, J. and Benner, R. (1996). Major biochemical composition of dissolved high molecular weight organic matter in sea water. Mar Chem 55:281-297.

Mueller-Niklas, G., Schuster, S., Kaltenboeck, E. and Herndl, G. J. (1994). Organic content and bacterial metabolism in amorphous aggregations of the northern Adriatic Sea. Limnol Oceanogr 39:58-68.

Neilsen, P. H. and Andreas, J. (1999) Extraction of EPS. In Microbial Extracellular Polymeric Substances: Characterization, Structure and Function, (Eds, Wingender, J., Neu, T., R. and Flemming, H.-C.) Springer-Verlag, New York, pp. 49-72.

Nichols, D. S., Sanderson, K., Buia, A., Van de Kamp, J., Holloway, P., Smith, M., Nichols, P. D. and Mancuso Nichols, C. (2001) Bioprospecting and Biotechnology in Antarctica. In The Antarctic: Past, Present and Future(Eds, Jabour-Green, J. and Haward, M.) Antarctic CRC, Hobart, Tasmania, pp. 8595.

Paerl, H. W. (1975). Microbial attachment to particles in marine and freshwater ecosystems. Microb Ecol 2:73-83.

Paerl, H. W. (1976). Specific associations of blue-green algae Anabaena and Aphanizomenon with bacteria in freshwater blooms. J Phycol 12:431-435.

Passow, U. (2000). Formation of transparent exopolymer particles, TEP, from dissolved precursor material. Mar Ecol-Prog Ser 192:1-11.

Passow, U. and Alldredge, A. (1994). Distribution, size and bacterial colonization of transparent exopolymer particles (TEP) in the ocean. Mar Ecol-Prog Ser 113:185-198.

Raguénès, G., Christen, R., Guezennec, J., Pignet, P. and Barbier, B. (1997a). Vibrio diabolicus sp.nov., a new polysaccharide-secreting organism isolated from a deep-sea vent polychaete annelid, Alvinella pompejana. Int $J$ Syst Bacteriol 47:989-995.

Raguénès, G. H. C., Peres, A., Ruimy, R., Pignet, P., Christen, R., Loaec, M., Rougeaux, H., Barbier, G. and Guezennec, J. G. (1997b). Alteromonas infernus sp. nov., a new polysaccharide-producing bacterium isolated from a deep-sea hydrothermal vent. J Appl Microbiol 82:422-430.

Rath, J., Wu, K. Y., Herndl, G. J. and Delong, E. F. (1998). High phylogenetic diversity in a marine-snow-associated bacterial assemblage. Aquat Microb Ecol 14:261-269. 
Roberts, I. S. (1996). The biochemistry and genetic of capsular polysaccharide production in bacteria. Ann Rev Microbiol 141:2023-2031.

Rougeaux, H., Guezennec, J., Carlson, R. W., Kervarec, N., Pichon, R. and Talaga, P. (1999). Structural determination of the exopolysaccharide of Pseudoalteromonas strain HYD 721 isolated from a deep-sea hydrothermal vent. Carbohydr Res 315:273-285.

Rougeaux, H., Pichon, R., Kervarec, N., Raguénès, G. H. C. and Guezennec, J. G. (1996). Novel bacterial exopolysaccharides from deep-sea hydrothermal vents. Carbohydr Polym 31:237-242.

Rue, E. L. and Bruland, K. W. (1995). Complexation of iron (III) by natural organic ligands in the Central North Pacific as determined by a new competitive ligand equilibrium/adsorptive cathode stripping voltametric method. Mar Chem 50:117-138.

Samain, E., Milas, M., Bozzi, L., Dubreucq, M. and Rinaudo, M. (1997). Simultaneous production of two different gel-forming exopolysaccharides by an Alteromonas strain originating from deep-sea hydrothermal vents. Carbohydr Polym 34:235-241.

Scharek, R., Vanleeuwe, M. A. and Debaar, H. J. W. (1997). Responses of southern ocean phytoplankton to the addition of trace metals. Deep-Sea Res Pt I/ 44:209-227.

Selbmann, L., Onofri, S., Fenice, M., Frederico, F. and Petriuccioli, M. (2002). Production and structural characterization of the exopolysaccharde of the Antarctic fungus Phoma herbarum CCFEE 5080. Res Microbiol 153:585-592.

Sidhu, M. S. and Olsen, I. (1997). S-layers of Bacillus species. Microbiology(UK) 143:1039-1052.

Simon, M., Alldredge, A. and Azam, F. (1990). Bacterial carbon dynamics on marine snow. Mar Ecol-Prog Ser 65:205-211.

Smith, D. C., Simon, M., Alldredge, A. and Azam, F. (1992). Intense hydrolytic enzyme activity on marine aggregates and implications for rapid particle dissolution. Nature 359:139-141.

Snelgrove, P. V. R. and Grassle, J. F. (1995). The deep-sea: desert and rainforest - debunking the desert analogy. Oceanus 38:25-28.

Spaeth, R., Flemming, H.-C. and Wuertz, S. (1998). Sorption properties of biofilms. Water Sci Technol 37:207-210.

Staley, J. T. and Gosink, J. J. (1999). Poles apart: Biodiversity and biogeography of sea ice bacteria. Ann Rev Microbiol 53:189-215. 
Stetter, K. O. (1998) Hyperthermophiles: isolation, classification and properties. In Extremophiles: Microbial Life in Extreme Environments, (Eds, Horikoshi, K. and Grant, W. D.) Wiley-Liss, New York, pp. 1-24.

Sullivan, C. W. and Palmisano, A. C. (1984). Sea ice microbial communities: distribution, abundance and diversity of ice bacteria in McMurdo Sound, Antarctica, in 1980. Appl Environ Microbiol 47:788-795.

Sutherland, I. W. (1972). Bacterial exopolysaccharides. Adv Microbial Phys 8:143-213.

Sutherland, I. W. (1977) Microbial exopolysaccharide synthesis. In Extracellular Microbial Polysaccharides, Vol. 45 (Eds, Sanford, P. A. and Laskin, A.) American Chemical Society, Washington, D.C., pp. 40-57.

Sutherland, I. W. (1979) Microbial exopolysaccharides: control of synthesis and acetylation. In Microbial Polysaccharides and Polysaccharases, (Ed, Berkeley, R. C. W.) Academic Press, New York, pp. 1-34.

Sutherland, I. W. (1980) Polysaccharides in adhesion of marine and freshwater bacteria. In Microbial Adhesion to Surfaces, (Ed, Berkeley, R. C. W.) Ellis Harwood Limited, Chichester, pp. 329-338.

Sutherland, I. W. (1982). Biosynthesis of microbial exopolysaccharides. Adv Microbial Phys 23:79-150.

Sutherland, I. W. (1994). Structure-function relationships in microbial exopolysaccharides. Biotechnol Adv 12:393-448.

Sutherland, I. W. (1998). Novel and established applications of microbial polysaccharides. Trends Biotechnol 16:41-46.

Sutherland, I. W. (1999) Biofilm exopolysaccharides. In Microbial Extracellular Polymeric Substances: Characterization, Structure and Function, (Eds, Wingender, J., Neu, T. R. and Flemming, H.-C.) Springer-Verlag, New York, pp. 73-92.

Sutherland, I. W. (2001). Biofilm exopolysaccharides: a strong and sticky framework. Microbiology-(UK) 147:3-9.

Szewzyk, U., Holmstrom, C., Wrangstadh, M., Samuelsson, M. O., Maki, J. S. and Kjelleberg, S. (1991). Relevance of the exopolysaccharide of marine Pseudomonas sp strain S9 for the attachment of Ciona intestinalis Larvae. Mar Ecol-Prog Ser 75:259-265.

Talmont, F., Vincent, P., Fontaine, T., Guezennec, J., Prieur, D. and Fournet, B. (1991). Structural investigation of an industrial exopolysaccharide from a deep-sea hydrothermal vent marine bacteria. Food Hydrocolloid 5:171-172.

Uhlinger, D. J. and White, D. C. (1983). Relationship between physiological status and formation of extracellular polysaccharide glycocalyx in Psuedomonas atlantica. Appl Environ Microbiol 45:64-70. 
van Loosdrecht, M. C., Lyklema, J., Norde, W., Scharaa, G. and Zehnder, A. J. (1987). The role of cell wall hydrophobicity in adhesion. Appl Environ Microbiol 1987:1893-7.

van Loosdrecht, M. C., Norde, W. and Zehnder, A. J. (1990). Physical chemical description of bacterial adhesion. J Biomater App/ 5:91-106.

Vincent, P., Pignet, P., Talmont, F., Bozzi, L., Fournet, B. and Guezennec, J. G. (1994). Production and characterization of an exopolysaccharide excreted by a deep-sea hydrothermal vent bacterium isolated from the polychaete annelid Alvinella pompejana. Appl Environ Microbiol 60:4134-4141.

Weiner, R. M. (1997). Biopolymers from marine prokaryotes. Trends Biotechnol 15:390-394.

White, D. C. (1986) Quantitative physiochemical characterization of bacterial habitats. In Methods and Special Applications in Bacterial Ecology, Vol. 2 (Eds, Poindexter, J. S. and Leadbetter, E. R.) Plenum Press, New York, pp. 177-203.

Williams, A. G. and Wimpenny, J. T. W. (1978). Exopolysaccharide production by Pseudomonas NCIB11264 grown in continuous culture. J Gen Microbiol 104:47-57.

Wingender, J., Neu, T., R. and Flemming, H.-C. (1999) What are bacterial extracellular polymer substances? In Microbial Extracellular Polymer Substances, (Eds, Wingender, J., Neu, T., R. and Flemming, H.-C.) Springer, Berlin, pp. 1-19.

Wolfaardt, G. M., Lawrence, J. R. and Korber, D. R. (1999) Function of EPS. In In Microbial Extracellular Polymeric Substances: Characterization, Structure and Function, (Eds, Wingender, J., Neu, T., R. and Flemming, H.-C.) Springer-Verlag, New York, pp. 171-200.

Wood, P., Caldwell, D. E., Evan, E., Jones, M., Korber, D. R., Wolfaardt, G. M., Wilson, M. and Gilbert, P. (1998). Surface-catalysed disinfection of thick Pseudomonas aeruginosa biofilms. J Appl Microbiol 84:1092-1098.

Wu, J. F., Boyle, E., Sunda, W. and Wen, L. S. (2001). Soluble and colloidal iron in the oligotrophic North Atlantic and North Pacific. Science 293:847-849.

Wuertz, S., Muller, E., Spaeth, R., Pfleiderer, P. and Flemming, H.-C. (2000). Detection of heavy metals in bacterial bofilms and microbial flocs with the fluorescent complexing agent Newport Green. J Ind Microbiol Biot 24:116123.

Yayanos, A. A. (1998) Empirical and theoretical aspects of life at high pressure in the deep-sea. In Extremophiles: Microbial Life in Extreme Environments, (Eds, Horikoshi, K. and Grant, W. D.) Wiley-Liss, New York, pp. 47-92. 
Zanchetta, P. and Guezennec, J. (2001). Surface thermodynamics of osteoblasts: relation between hydrophobicity and bone active biomaterials. Colloids and Surfaces 22:301-307.

Zanchetta, P., Lagarde, M. and Guezennec, J. (2003a). A new bone-healing material: A hyaluronic acid-like bacterial exopolysaccharide. Calcif Tissue Int 72:74-79.

Zanchetta, P., Lagarde, N. and Guezennec, J. (2003b). Systematic effects on bone healing of a new hyaluronic acid-like bacterial exopolysaccharide. Calcif Tissue Int 73:232-236.

Zobell, C. E. (1943). The effect of solid surfaces upon bacterial activity. $J$ Bacteriol 46:75-82. 


\section{FIGURES}

Figure 1 Repeating unit of the exopolysaccharide secreted by Pseudoalteromonas sp. strain 721 (Guezennec 2002).

Figure 2 Repeating unit of the exopolysaccharide produced by Alteromonas sp. strain 1644 (Guezennec 2002).

Figure 3 Repeating unit of the exopolysaccharide secreted by Alteromonas. macleodii subsp. fijiensis (Guezennec 2002).

Figure 4 Repeating unit of the exopolysaccharide secreted by Vibrio diabolicus (Guezennec 2002). 


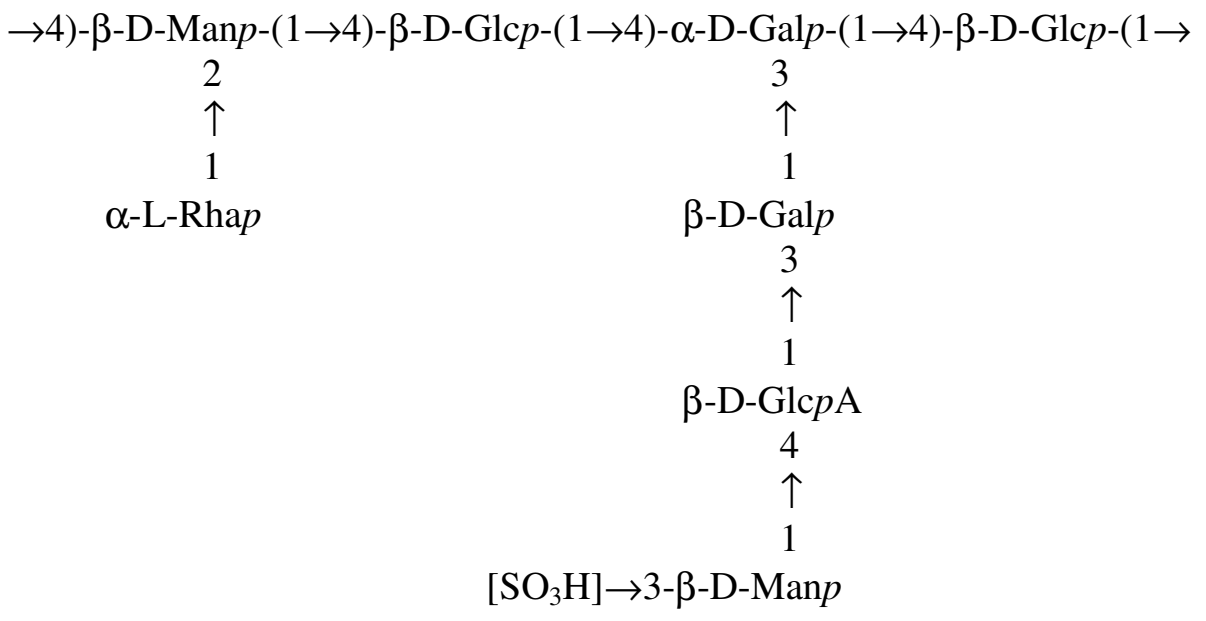

Figure 1 


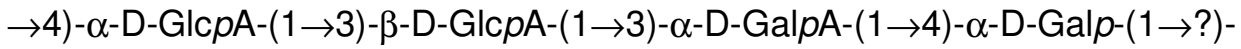
Hexose $(1 \rightarrow$

4
$\uparrow$
1
$\beta-D-G l c p$
4
$\uparrow$
1
$\alpha \beta$ ?-D-Galp
3
$\uparrow$
1
3-O-Lac- $\beta$-D-GlcpA

Figure 2 


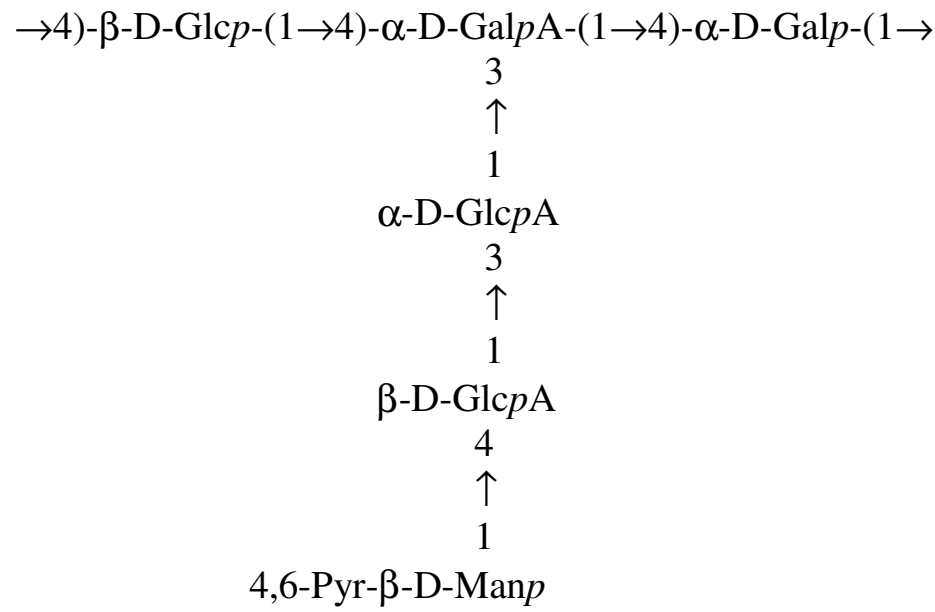

Figure 3 
$\rightarrow 3)-\beta-D-G l c p N A c-(1 \rightarrow 4)-\beta-D-G l c p A-(1 \rightarrow 4)-\beta-D-G l c p A-(1 \rightarrow 4)-\alpha-D-G a l p N A c-(1 \rightarrow$

Figure 4 
Table 1. Sugar and non-sugar components of bacterial exopolysaccharides*

\begin{tabular}{|c|c|c|c|}
\hline Type & Component & Example & Mode of linkage \\
\hline \multirow[t]{4}{*}{ Sugar } & Pentoses & $\begin{array}{l}\text { D-Arabinose } \\
\text { D-Ribose } \\
\text { D-Xylose }\end{array}$ & \\
\hline & Hexoses & $\begin{array}{l}\text { D-Glucose } \\
\text { D-Mannose } \\
\text { D-Galactose } \\
\text { D-Allose } \\
\text { L-Rhamnose (6-Deoxy-L-mannose) } \\
\text { L-Fucose (6-Deoxy-L-galactose) }\end{array}$ & \\
\hline & Amino sugars & $\begin{array}{l}\text { D-Glucosamine (2-Amino-2-deoxy-D-glucose) } \\
\text { D-Galactosamine (2-Amino-2-deoxy-D-galactose) }\end{array}$ & \\
\hline & Uronic acids & $\begin{array}{l}\text { D-Glucuronic acid } \\
\text { D-Galacturonic acid }\end{array}$ & \\
\hline Non-sugar & $\begin{array}{l}\text { Acetic acid } \\
\text { Succinic acid } \\
\text { Pyruvic acid } \\
\text { Phosphoric acid } \\
\text { Sulfuric acid }\end{array}$ & & $\begin{array}{l}\text { O-Acyl, } N \text {-Acyl } \\
\text { O-Acyl } \\
\text { Acetal } \\
\text { Ester, diester } \\
\text { Ester }\end{array}$ \\
\hline
\end{tabular}

* adapted from Kenne L, Lindberg B (1983) Bacterial Polysaccharides.

In: Aspinall GO (ed) The Polysaccharides. Academic Press, New York, pp 287-363 
Table 2. Examples of characterized marine bacterial exopolysaccharides from Antarctic and deep-sea hydrothermal vent sources

\begin{tabular}{|c|c|c|c|c|c|c|}
\hline Microorganism & Source environment & Description of EPS & $\begin{array}{l}\text { Distinguishing } \\
\text { characteristics }\end{array}$ & $\begin{array}{l}\text { Suggested } \\
\text { ecological role }\end{array}$ & $\begin{array}{l}\text { Biotechnological } \\
\text { application }\end{array}$ & Reference \\
\hline $\begin{array}{l}\text { Pseudoalteromonas sp. (strain } \\
\text { CAM025, bacteria) }\end{array}$ & $\begin{array}{c}\text { Filtered sea ice } \\
\text { particulates, Antarctica }\end{array}$ & $\begin{array}{c}\text { Sulfated heteropolysaccharide, } \\
\text { high in uronic acids with acetyl } \\
\text { groups }\end{array}$ & $\begin{array}{l}\text { High* molecular } \\
\text { weight }\left(5.7 \times 10^{6}\right. \\
\text { Da) }\end{array}$ & $\begin{array}{l}\text { Cryprotection in } \\
\text { sea ice brine } \\
\text { channels }\end{array}$ & $-\wedge$ & $\begin{array}{l}\text { Mancuso Nichols } \\
\text { et al. } 2004\end{array}$ \\
\hline $\begin{array}{l}\text { Pseudoalteromonas sp. (strain } \\
\text { CAM036, bacteria) }\end{array}$ & $\begin{array}{l}\text { particulates from } \\
\text { Southern Ocean }\end{array}$ & $\begin{array}{l}\text { Sulfated heteropolysaccharide, } \\
\text { high in uronic acids with acetyl } \\
\text { and succinyl groups }\end{array}$ & $\begin{array}{l}\text { High* molecular }^{*} \\
\text { weight (1.7 MDa) }\end{array}$ & $\begin{array}{c}\text { Trace metal } \\
\text { binding in iron } \\
\text { depleted Southern } \\
\text { Ocean } \\
\end{array}$ & - & $\begin{array}{l}\text { Mancuso Nichols } \\
\text { et al. } 2004\end{array}$ \\
\hline HYD-1545 (bacteria) & $\begin{array}{c}\text { Tissue of marine } \\
\text { polychaete from deep- } \\
\text { sea hydrothermal vent } \\
\text { (HTV) habitat }\end{array}$ & $\begin{array}{c}\text { Sulfated heteropolysaccharide, } \\
\text { high in uronic acids, with } \\
\text { pyruvate }\end{array}$ & $\begin{array}{l}\text { High uptake of } \\
\text { heavy metals }\end{array}$ & - & - & $\begin{array}{l}\text { Vincent et al. } \\
\quad 1994\end{array}$ \\
\hline $\begin{array}{l}\text { Alteromonas macleodii subsp. } \\
\text { fijiensis (bacteria) }\end{array}$ & $\begin{array}{l}\text { Seawater, deep-sea } \\
\text { HTV, North Fijian Basin }\end{array}$ & $\begin{array}{c}\text { Sulfated heteropolysaccharide, } \\
\text { high in uronic acids, with } \\
\text { pyruvate }\end{array}$ & $\begin{array}{l}\text { High uptake of } \\
\text { lead, cadmium and } \\
\text { zinc }\end{array}$ & - & $\begin{array}{l}\text { Thickening agent in food- } \\
\text { processing industry, } \\
\text { biodetoxification and } \\
\text { wastewater treatment, } \\
\text { bone healing, treatment of } \\
\text { cardio-vascular deseases }\end{array}$ & $\begin{array}{l}\text { Rougeaux et al. } \\
\text { 1996, Loaec et } \\
\text { al. 1997, Colliec- } \\
\text { Joult et al. } 2001\end{array}$ \\
\hline $\begin{array}{c}\text { Pseudoalteromonas } s p \text {. (strain } \\
\text { GY } 768, \text { similar to } P . \\
\text { carrageenovora, bacteria) }\end{array}$ & $\begin{array}{l}\text { Invertebrate tissues, } \\
\text { deep-sea HTV, } \\
\text { Guaymus Basin }\end{array}$ & $\begin{array}{c}\text { Sulfated (13\%) } \\
\text { heteropolysaccharide, high in } \\
\text { uronic acids, with pyruvate and } \\
\text { acetate } \\
\end{array}$ & $\begin{array}{l}\text { Polyelectrolyte } \\
\text { character }\end{array}$ & - & $\begin{array}{l}\text { Biodetoxification and } \\
\text { wastewater treatment, } \\
\text { bone healling }\end{array}$ & $\begin{array}{c}\text { Rougeaux et al. } \\
\text { 1996, Zanchetta } \\
\text { and Guezenec } \\
2001 \\
\end{array}$ \\
\hline $\begin{array}{c}\text { Pseudoalteromonas } s p \text {. (strain } \\
\text { GY } 786 \text {, similar to } P \text {. undina, } \\
\text { bacteria) }\end{array}$ & $\begin{array}{l}\text { Invertebrate tissues, } \\
\text { deep-sea HTV, } \\
\text { Guaymus Basin }\end{array}$ & $\begin{array}{c}\text { Sulfated }(6.5 \%) \\
\text { heteropolysaccharide, high in } \\
\text { uronic acids, with pyruvate and } \\
\text { acetate }\end{array}$ & $\begin{array}{l}\text { Polyelectrolyte } \\
\text { character }\end{array}$ & - & $\begin{array}{l}\text { Biodetoxification and } \\
\text { wastewater treatment }\end{array}$ & $\begin{array}{c}\text { Rougeaux et al. } \\
1996\end{array}$ \\
\hline Vibrio sp. (bacteria) & $\begin{array}{l}\text { Invertebrate tissues, } \\
\text { deep-sea HTV } 9^{\circ} \mathrm{N} \\
\text { East Pacific Rise }\end{array}$ & $\begin{array}{c}\text { Heteropolysaccharide high in } \\
\text { uronic acids and amino sugars, } \\
\text { traces of neutral sugars (EPS } \\
800 \text { ) }\end{array}$ & Similar to heparin & - & $\begin{array}{c}\text { Anticoagulant activity, anti- } \\
\text { HIV activity, } \\
\text { pharmaceutical activity }\end{array}$ & $\begin{array}{l}\text { Rougeaux et al. } \\
1996\end{array}$ \\
\hline $\begin{array}{l}\text { Alteromonas infernus (strain } \\
\text { GY 685, bacteria) }\end{array}$ & $\begin{array}{l}\text { Seawater from Riftia } \\
\text { pachyptila, deep-sea } \\
\text { HTV, Guaymas Basin }\end{array}$ & $\begin{array}{l}\text { Two EPS, EPS-1 associated } \\
\text { with cells, rich in uronic acid } \\
\text { and protein; EPS-2: } \\
\text { heteropolysaccharide with } \\
\text { uronic acids }\end{array}$ & - & - & $\begin{array}{l}\text { Biodetoxification and } \\
\text { wastewater treatment }\end{array}$ & $\begin{array}{l}\text { Raguénès et al. } \\
1997\end{array}$ \\
\hline
\end{tabular}

* average molecular weight of most marine bacterial EPS: $0.1-0.3 \times 10^{6}$ Da (Decho et al 1990)

$\wedge$ none mentioned 
Table 3. Some of the roles of microbial exopolymeric material in the marine environment

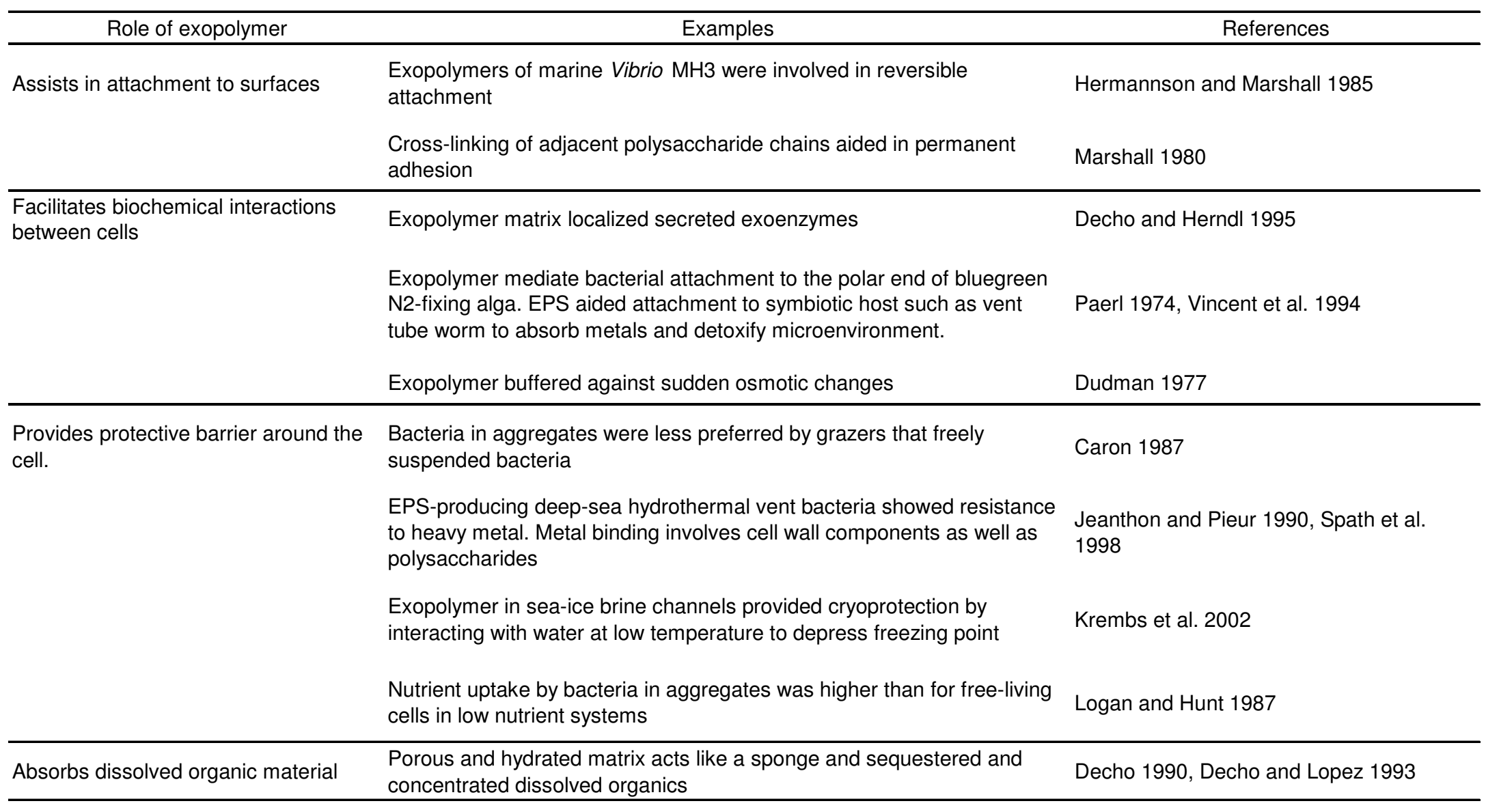

